\title{
CLASSROOM MANAGEMENT STYLES AND TEACHER - STUDENT RELATIONSHIP CONGRUENCY: ITS INFLUENCE ON STUDENT LEARNING OUTCOMES
}

\section{ABSTRACT}

Bui Thi Kieu Giang*, Tran Thi Thuy Nga TNU University of Agriculture and Forestry

This study investigated the congruency of the classroom management styles and teacher-student relationship as well as its influence on student learning outcomes. The classroom management styles are categorized as authoritarian, autocratic, democratic and laissez faire. The study employed the quantitative aspect which was the determination of the profile, classroom management styles, teacher-student relationship and the learning outcomes. The respondents were the teachers and students at Thai Nguyen University during the school year 2018-2019. A total of 1,703 students and 92 teachers were chosen through a convenience sampling method. The findings imply that teachers place limits and controls on the students but simultaneously encourage independence. There is a significant relationship between teacher-student relationships with the classroom management, which influences the way teachers manage their classrooms. Moreover, the congruency of the relationship implies that the more favorable the teacher-student relationship is, the higher the extent of learning is. In short, students are able to learn more when they experience healthy teacher-student relationship.

Keywords: Autocratic management style; authoritarian management style; democratic management style; laissez-faire management style.

Received: 25/02/2019; Revised: 15/3/2019; Approved: 07/5/2019

\section{CÁCH QUẢN LÝ LỚP HỌC VÀ SỰ HÀI HOÀ MỐI QUAN HÊ GIẢNG VIÊN - SINH VIÊN: SỬ TƯƠNG TÁC CỦA MỐI QUAN Hệ ĐÓ ẢNH HƯỞNG ĐẾN KẾT QUẢ HỌC TẬP CỦA SINH VIÊN}

TÓM TẮT

Bùi Thị Kiều Giang*, Trần Thị Thuý Nga Trường Đại học Nông Lâm - ĐH Thái Nguyên

Nghiên cứu này xem xét sự hài hoà cách quản lý lớp học của giảng viên và mối quan hệ giảng viên - sinh viên ảnh hưởng đến kết quả học tập của sinh viên. Cách quản lý lớp học được phân loại thành: cách quản lý độc đoán, chuyên quyền, dân chủ và trao quyền tự quyết. Phương pháp định lượng được sử dụng trong nghiên cứu nhằm xác định mô tả sơ lược đối tượng nghiên cứu, cách quản lý lớp học, mối quan hệ giảng viên - sinh viên và kết quả học tập của sinh viên. Đối tượng nghiên cứu là giảng viên và sinh viên tại Đại học Thái Nguyên trong năm học 2018-2019. Tổng số 1.703 sinh viên và 92 giảng viên được lựa chọn thông qua phương pháp chọn mẫu thuận tiện. Kết quả nghiên cứu chỉ ra rằng giảng viên xác định giới hạn và kiểm soát đối với sinh viên nhưng đồng thời khuyến khích sự tự do của sinh viên. Nghiên cứu cũng chỉ ra rằng có sự liên hệ giữa mối quan hệ giảng viên - sinh viên với cách quản lý lớp học, điều này ảnh hưởng đến cách giảng viên tổ chức hoạt động giảng dạy trên lớp. Ngoài ra, sự hài hoà của mối quan hệ giảng viên - sinh viên hàm ý rằng mối quan hệ đó càng hài hoà bao nhiêu thì kết quả học tập của sinh viên càng tốt bấy nhiêu. Nói tóm lại sinh viên có thể học được nhiều hơn khi mối quan hệ giữa giảng viên và sinh viên có sự đồng thuận.

Từ khoá: Cách quản lý độc đoán; cách quản lý chuyên quyền; cách quản lý dân chủ; cách quản lý trao quyền tụ quyết

Ngày nhận bài: 25/02/2019; Ngày hoàn thiện: 15/3/2019; Ngày duyệt đăng: 07/5/2019

* Corresponding author. Email: buithikieugiang@tuaf.edu.vn

DOI: https://doi.org/10.34238/tnu-jst.2019.06.333 


\section{Introduction}

Teaching is a very complex activity that is affected by the subject matter, the time available, the character of the teacher, the disposition of the learners, resources, etc. While all of these factors play a pivotal role in ensuring a successful teaching, it is an accepted fact that the interpersonal relationship between teachers and students has a significant role to play in the teaching and learning process. A pleasant classroom environment from an interpersonal perspective on teaching undeniably creates and maintains a positive, warm classroom atmosphere conducive to learning [1]. This is because the teachers as well as the students need to feel comfortable in their classrooms to make teaching and learning interesting, fun and meaningful.

Educators create the culture of success in schools through the effective implementation of classroom management and discipline. In fact, teachers play a key role in classroom management to create a proactive learning environment. According to Norris (2003) [2], classroom management refers to creating parameters for the social, emotional, physical, and intellectual environments, which allows for optimized teaching and learning to occur. There are essential approaches to develop interpersonal relationships between the teachers and the students. Different teachers advocate different levels of control over their students. Some teachers prefer a disciplined environment for learning, whereas others want to create a pleasant classroom atmosphere where students feel safe to take risks and be creative.

One of the basic tenets of classroom management is that the kind of classroom management styles (CMSs), educators employ inside the class, fundamentally influences their relationship or interactions with the students. This happens as the different CMSs foster positive and negative interactions between the teachers and students. Some teachers typically interact with students in negative ways: criticizing a student's poor posture, pointing out mistakes, making sarcastic remarks about inappropriate social behavior, frowning to show disapproval, among others. Often, these teachers consider it their job to point out where the students have gone wrong. "You learn from your mistakes" seems to be their mantra. Other teachers typically interact with students in positive ways: complimenting a student's good posture, pointing out successes, making flattering remarks about appropriate social behavior, smiling to show approval, to name a few. These teachers take the view that "Success is the best teacher."

According to Latham (2002) [3], CMSs consistently correlate with differences in student behavior. His research reveals that in classrooms where students are on task attending, following instructions, and participating appropriately, the ratio of positive to negative interactions between teachers and students was eight to one. These teachers are saying pleasant, positive, encouraging things to their students or they are smiling, touching, and gesturing in pleasant ways eight times for every one time that they criticized, frowned, or the like. Some of the researches on CMSs have also found out that teachers feel more in control and more competent when they have a formal plan for discipline and procedures [4]. Thus, when teachers can focus less on discipline they can shift their attention to refining a methodology that bolsters higher achievement. According to Jerry (1982) [5], there are some basic approaches to CMSs namely: authoritarian, autocratic, democratic and permissive or laissez faire. The democratic management style provides an aura of freedom in the classroom where students are at liberty to express their feelings and need but the final decision rests on the 
teacher. In contrast, the autocratic style suggests a coercive and dictatorial style of classroom management. Teachers using this style rely on their own experience, knowledge and understanding ignoring the opinion of the learner. The laissez-faire style, on the other hand, represents total freedom with no input whatsoever from the teacher.

The main aim of this investigation is to determine the influence of the congruency of CMSs of the teachers and teacher-student relationship toward student learning outcomes. It is hoped that this study will provide insight into the area of CMSs and discipline and that this will serve as a valuable tool in understanding the CMSs and interpersonal relationships between teachers and students to get the best student learning outcomes. The study tests two hypothesis, that is, if there is no significant relationship between the CMSs, teacher-student relationship and extent of learning outcomes; if there is a significant relationship between CMSs of the teachers and their profile variables when grouped according to their profile variables. The study was limited to Thai Nguyen University (TNU) during the school year 2018-2019.

\section{Methodology}

The study is based on quantitative method. The quantitative aspect was the determination of the profile, CMSs, teacher-student relationship and the learning outcomes. Along with this concern, descriptive correlational research was employed as it tested if there is no significant relationship between CMSs, student teacher relationship and extent of learning outcomes. The respondents were the teachers and students at Thai Nguyen University. A total of 1,703 students and 92 teachers were chosen through a convenience sampling method [6]. The quantitative data was analyzed using descriptive statistics. Specifically, frequency count, percentage and mean were used to analyze the profile of the teacher respondents, their classroom management style, the teacher-student relationship and the learning outcomes. Furthermore, Pearson Product Moment Correlation was used to test the hypotheses of the study.

\section{Results and discussion}

When asked about the profile of the teachers, the results showed that majority of the respondents are female with 65 or $70.7 \%$ and only 27 or $29.3 \%$ are male respondents. It can be inferred that men are not interested in becoming teachers. As regards age, 18 or $19.6 \%$ are aged $36-40$; and 17 or $18.5 \%$ have ages ranging from 26-30 and 31-35. Moreover, 12 or $13.0 \%$ are in the age range of $20-25$ and 11 or $12 \%$ are aged $46-50$; 9 or $9.8 \%$ are aged $41-45 ; 8$ or $8.7 \%$ are $51 \&$ above. The mean age of the respondents is 35 , which is considered quite young in comparison with the age of retirement. With respect to educational attainment, most of the respondents have obtained master's degrees with 45 or $48.9 \%$, then following doctoral degrees with 29 or $31.5 \%$, and 18 or $19 \%$ are with bachelor's degrees. In general, the university policies and incentives are mobilized to standardize the lecturers' standards in all universities. As regarding number of years in the service, majority of the respondents are young in the service, namely 16 or $17.4 \%$ have served from $6-10$ years. 16 or $17.4 \%$ have taught for 1-5 and 11-15 years. Moreover, 10 or $10.9 \%$ have been in the service for $21-25$ years, 9 or $9.8 \%$ have taught for $16-20$ years and 7 or $7.6 \%$ have worked from 26 years and more. It can be inferred that the teaching staff are qualified and experienced enough to implement any instructional methodologies on their teaching careers. In terms of universities participation, most or 28 or $30.4 \%$ are from Thai Nguyen University of Agriculture and Forestry, 17 or $18.5 \%$ are from Thai Nguyen University of Education, 15 or $16.3 \%$ come from Thai 
Nguyen University of Medicine and Pharmacy and 11 or $12 \%$ are from Thai Nguyen University of Sciences. The least number of teachers are with Thai Nguyen University of Economics and Business Administration (6 or 6.5\%) and Thai Nguyen University of Communication \& Information Technology (4 or 4.3\%). Thus, seven universities were involved in this study, which ensures the equality and liability of the findings. Unfortunately, there was bias in the provision of the participants, which might not reflect thorough viewpoints.

Table 1 presents the frequency and percentage distribution of the CMSs of the teachers as perceived by the students and teachers themselves. It can be gleaned from the table that 700 or $39 \%$ are utilizing authoritarian style, 364 or $20.28 \%$ are users of eclectic style, 336 or $18.72 \%$ have democratic style, 268 or $14.93 \%$ are utilizing autocratic style and 127 or $7.08 \%$ are using laissez faire. The highest use of authoritarian style by the teachers indicates they have high expectations of appropriate behavior, they have clear

Table 1. Frequency and percentage distribution of CMSs of teachers as perceived by the students and teachers themselves

\begin{tabular}{|c|c|c|c|c|c|c|}
\hline \multirow{2}{*}{ Classroom Management Style } & \multicolumn{2}{|c|}{ Teachers } & \multicolumn{2}{|c|}{ Students and Teachers } & \multicolumn{2}{|c|}{ Total } \\
\hline & Freq. & $\%$ & Freq. & $\%$ & Freq. & $\%$ \\
\hline Authoritarian & 52 & 56.40 & 648 & 38.05 & 700 & 39.00 \\
\hline Autocratic & 1 & 0.01 & 267 & 15.68 & 268 & 14.93 \\
\hline Democratic & 15 & 16.85 & 321 & 18.85 & 336 & 18.72 \\
\hline Laissez-Faire & 3 & 3.50 & 124 & 7.28 & 127 & 7.08 \\
\hline Eclectic & 21 & 23.30 & 343 & 20.14 & 364 & 20.28 \\
\hline Total & 92 & 100 & 1,703 & 100 & 1795 & 100 \\
\hline
\end{tabular}

Table 2. Comparison between the assessments of the teachers and students on the teachers' CMSs

\begin{tabular}{cccccc}
\hline Group & Mean & SD & Std. Error of Difference & t-value & Probability \\
\hline Teachers & 35.38 & 5.493 & 0.582 & \multirow{2}{*}{$4.104^{* *}$} & 0.000 \\
\hline Students & 37.77 & 4.230 & 0.58 & \\
\hline
\end{tabular}

$* *=$ significant at .01 level

It was hypothesized that there is no significant difference in the assessment of the teachers and students the teachers' classroom management style. Table 2 showing the comparison between the assessment of the teachers and students on the teachers' classroom management style reveals that there is a significant difference in the assessment of both respondents at 0.01 level of significance. The $\mathrm{t}$-value for this comparison is 4.104 with a probability of 0.000 and with a 
standard error of difference at 0.582 . This finding reveals that the hypothesis is rejected as there is a significant difference in the assessment of the teachers and students on the teachers' classroom management style. The students have more favorable rating to their teachers than the rating of the teachers to themselves as reflected in the mean of 37.77 for the students and 35.38 for the teachers. The finding indicates the belief of the teachers that CMSs are just suggestive in nature, which is recommendatory to teachers based on the kind of learning environments that they are into.

Table 3. Interrelationship among CMSs of the teachers, teacher-student relationship congruency and extent of learning

\begin{tabular}{|c|c|c|c|}
\hline Variables & $\begin{array}{c}\text { Classroom } \\
\text { Management Style }\end{array}$ & $\begin{array}{l}\text { Teacher - Student } \\
\text { Relationship } \\
\text { Congruency }\end{array}$ & $\begin{array}{l}\text { Extent of } \\
\text { Learning }\end{array}$ \\
\hline Classroom Management Style & - & & \\
\hline Teacher-Student Relationship & $\begin{array}{l}0.252^{*} \\
(0.015)\end{array}$ & - & \\
\hline Extent of Learning Outcomes & $\begin{array}{l}0.349^{* *} \\
(0.001)\end{array}$ & $\begin{array}{l}0.342^{* *} \\
(0.001)\end{array}$ & - \\
\hline
\end{tabular}

** = significant at 0.01 level

$*$ = significant at 0.05 level

It was hypothesized in the study that there is a significant relationship between CMSs of the teachers, teacher - student relationship and extent of learning outcomes. Table 3 reveals that the hypothesis is rejected at .05 level of significance. The significant relationship between teacher student relationship with CMSs is reflected in the correlation coefficient of 0.252 and probability value of 0.015 . On the other hand, the significant relationship between extent of learning and classroom management is seen in the computed correlation coefficient of 0.349 and probability value of 0.001 while the relationship between extent of learning with teacher - student relationship congruency is indicated in the correlation coefficient of 0.342 and 0.001 probability value. The significant relationship between teacher - student relationship with the classroom management means that healthy and sound teacher-student relationship influences to a great extent how teachers establish and enforce routines and rules inside the classroom and how they plan and prepare the instructional materials. Besides, the significant relationship between the extent of learning with teacher - student relationship indicates that the better the teacher-student relationship is, the higher the extent of learning is. In short, students are able to learn more when they experience healthy teacher student relationship.

Table 4. Relationship between the CMSs of the teachers and their select profile variables

\begin{tabular}{lccl}
\hline \multicolumn{1}{c}{ Variable } & Correlation Coefficient & Probability & Statistical Inference \\
\hline Sex & 0.114 & 0.277 & Not significant \\
Age & 0.062 & 0.518 & Not significant \\
Educational Attainment & 0.257 & 0.013 & Significant at 0.05 \\
Number of years in the service & 0.119 & 0.257 & Not significant \\
Universities & -0.059 & 0.577 & Not significant \\
\hline
\end{tabular}

It was hypothesized in the study that there is service and universities. Thus, the null no significant relationship between the CMSs hypothesis is accepted only for the of the teachers and their profile variables. educational attainment variable. It is Table 4 reveals that educational attainment suggested that the use of CMSs is influenced has significant relationship with CMSs but by the level of educational attainment of the not for sex, age, number of years in the teachers. The higher educational attainment 
provides more theories, principles and insights about teaching and learning. The positive relationship between the classroom management style of the teachers and their educational attainment is supported by earlier researches [8], [9]; their findings reveal that having successful classroom management skills are thought to be necessary in fostering effective student learning. Teachers who are weak at classroom management skills should be provided with necessary theoretical approaches and classroom disciplines as well as useful tips on implementation.

\section{Conclusions}

On the basis of the foregoing findings, the study concludes that TNU teachers are indeed second parents to their students considering that they serve as 'loco parentis' to their students. There is substantial imposition of rules but there is also promotion of independence. Interestingly, there is also a healthy connection between the teachers and students inside the classroom which is manifested in the low teacher anxiety. Teachers and students cultivate their relationships and use this healthy relationship to ensure a "nurturing pedagogy". Moreover, the study concludes that there exists a congruency between classroom management style and teacher - student relationship as well as student learning outcomes. The extent of learning obtained by the students is to a great extent determined by the kind of CMSs utilized by the teachers. Of all CMSs, it is the authoritarian style that plays a crucial role in determining higher learning. Finally, the study proves that the teacher student relationship positively influences CMSs of the teachers. It also asserts that the teacher - student relationship is positively associated by the degree of learning that takes place inside the classroom; with classroom management style as well as teacher - student relationship.

\section{REFERENCES}

[1]. Williams, M. and Burden, R., Psychology for Language Teachers: A Social Constructivist Approach. Cambridge University Press, Cambridge, 1997.

[2]. Norris J. A., Looking at Classroom Management Through a Social and Emotional Learning Lens. Classroom Management in a Diverse Society. Vol. 42, Iss. 4, pp. 313-318, 2003. https://doi.org/10.1207/s15430421tip4204_8

[3]. Latham, G. I., Behind the schoolhouse door: Eight skills every teacher should have. In G.I. Latham, Behind the schoolhouse door: Managing chaos with science, skills, and strategy (pp. 11-41). North Logan, UT: P \& T Ink. 2002.

[4]. Charles C. M., Today's best classroom management strategies: paths to positive discipline. Boston: Pearson/Allyn Bacon, 2008.

[5]. Jerry D. L., Three Approaches to Classroom Management: Views from a Psychological Perspective. The Educational Forum. Vol 48, Iss. 1. pp. 124-125, 1982. https://doi.org/10.1080/00131728309335886

[6]. Given L. M., Convenience Sample. The SAGE Encyclopedia of Qualitative Research Methods. SAGE Publications, 2008. https://doi.org/10.4135/9781412963909.n68

[7]. Dunbar, C. Jr., Classroom Management (Monograph). East Lansing, MI. Michigan State University Outreach, 2004.

[8]. Emmer, E., \& Aussiker, A., School and classroom discipline pro- grams: How well do they work? In O. C. Moles (Ed.), Student discipline strategies: Research and practice (pp. 129-166). Albany, NY: SUNY Press, 1990.

[9]. Jones, F., \& Jones, L.S., Comprehensive Classroom management. Boston: Allyn \& Bacon, 2001. 